\title{
Comparisons of earthworm community structure between different ecotypes
}

\author{
Ma. Theresa C. Pareño*, Cesar G. Demayo
}

Department of Biological Science, College of Science and Mathematics, Institute of Technology, Iligan City 9200, Philippines

\section{A R T I C L E I N F O}

Article history:

Received 20 February 2017

Received in revised form

25 July 2017

Accepted 25 July 2017

\section{Keywords:}

Clay-loam soil

Thermal property

Single probe

Moisture content

Bulk density

\begin{abstract}
A B S T R A C T
The Philippines is considered to be a biodiversity "hotspot" of high species richness and endemism but the increased in human population and the destruction of the environment triggered the decline of biodiversity. Habitat complexity and the specialized niches available to animals are lost due to deforestation and anthropogenic activities. As good bioindicators and soil ecosystem engineers, earthworms play an important role for the decomposition, remediation of the soil in the form of their casts and food source for the other animals. This study was conducted to determine the biodiversity of earthworms from 3 different ecotypes namely forest, riverbank, and agricultural area. To determine on to what genus they belong, there were a total of 64 morphological characters that were used. There are a total of 4 genera that were identified from the 3 families namely, Eudrilidae, Megascolecidae, and Glossoscolecidae. The 4 genus were namely, Eudrilus eugeniae, $P$. corethrurus, and 2 pheretima $s p$. This study shows that these species were actually invasive that even in the forest they are still present. But results show the forest has the most number of species compared to the other ecotypes like river and agricultural area.
\end{abstract}

(C) 2017 The Authors. Published by IASE. This is an open access article under the CC BY-NC-ND license (http://creativecommons.org/licenses/by-nc-nd/4.0/).

\section{Introduction}

The Philippine ecosystem is characterized by a high degree of biological diversity. However, population pressure, poverty and survival needs have resulted in rapid destruction of the environment. It is thought that about $90 \%$ of Philippine land area was once forested. But due to massive forest exploitation, excessive annual cuts and weak reforestation efforts it dropped to less than $20 \%$. Based on the analysis almost 9.8 million hectares of forests were lost. If the current rate of deforestation is maintained, it is projected that there will be no forest covers within the next decade (Suarez and Sajise, 2010). Earthworm populations have been recognized as bio-indicators of soil fertility and health, because earthworm improves soil properties by playing an active role in the decomposition of organic materials, nutrient cycling, soil formation, and the improvement of soil structure by channeling and bioturbation (Fragoso and Lavelle, 1992; Liu and Zou, 2002).

\footnotetext{
* Corresponding Author

Email Address: theresa_rez@yahoo.com (M. T. C. Pareño) https://doi.org/10.21833/ijaas.2017.09.013

2313-626X/C 2017 The Authors. Published by IASE.

This is an open access article under the CC BY-NC-ND license

(http://creativecommons.org/licenses/by-nc-nd/4.0/)
}

The differences in habitat preferences may affect the community structure of earthworms in sites altered by land-use changes. In Banaue rice terraces, there's a major threat because of the earthworms. These are called the giant earthworms, known as the species under Polypheretima elongata and another unknown species under the genus Pheretima. They cause major threat because they burrow holes in the landscape resulting a landslide or the destruction of the landscape where the rice is usually grown. They made it to the rice terraces because of the destruction of their habitats. In recent years, the increasing global trade, travel, and transport had rapidly increased the rate of introduction and diversity of alien species (Paoletti, 1999). There are several species of earthworms that are invasive nonnative ones and to mention a few are as follows: Pontoscolex. corethrurus (origin Brazil), Polypheretima elongata (origin SE Asia, probably Indonesian region), Amynthas corticis (origin mainland E Asia), Dichogaster saliens (origin Africa), Nematogenia occidentalis (origin unclear), Perionyx excavates (origin India).

The need to conduct such surveys on earthworms is accentuated by the rapid destruction of forest communities particularly in the tropics (Rickart et al., 1991). Assessment surveys of earthworm communities are increasingly used to determine 
conservation priorities. Quantifying the Earthworm communities has gained increasing importance in environment impact assessments, planning of conservation, and also ecological research. This study determines to examine the influence of environmental changes on earthworm community structure.

\section{Materials and methods}

\subsection{Collection of samples}

Samples were collected through opportunistic sampling from the different ecotypes such as river, forest and agricultural area one to two feet below the ground. Collected earthworms were then washed with water and fixed with ethyl alcohol for preservation. Earthworms were preserved using $80 \%$ of ethanol and put in the screw capped test tube for the morphological examination.

\subsection{Morphological analysis}

Segmentation of earthworms support diversified functions of body parts and tissues. Fig. 1 represents the anatomy of the earthworms and their basic body parts. There are a total of 64 characters represented by codes were used in the examination. The characters were based on the study of Apuan et al. (2010), 6 additional characters from the study of James (2004) and 2 additional characters by Gates (1972).

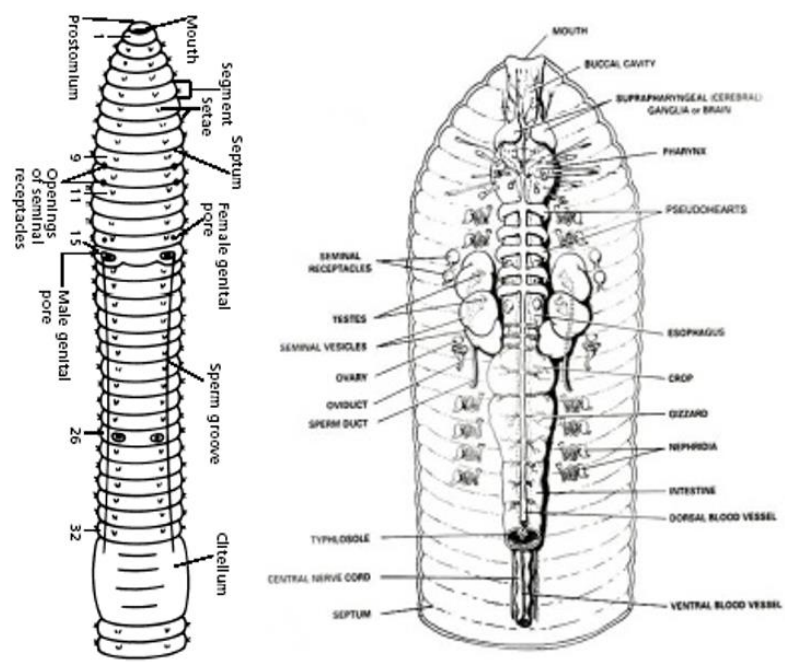

Fig. 1: External and internal morphology of Earthworms

\section{Results}

There are a total of 5 species of earthworms under the family Eudrilidae, Megascolecidae, Glossoscolecidae were identified (Figs. 2-5).

$P$. corethrurus (Fig. 2) is characterized by the obvious external feature of clitellum that is saddle shaped and is covered by 7 to 9 segments from the anterior, the setae is arranged 8 setae per segment and is single pointed. The pigmentation of this species is unpigmented to slightly pink.
Eudrilus eugeniae has an obvious external feature like the purple sheen and the posterior segments are evenly tapered to a point (Blackburn, 1989). They have sizes that ranges from about $10 \mathrm{~cm}$ in length to huge specimens of over $12 \mathrm{~cm}$ and size may depend on habitat (Segun, 1998). They are known to contribute to soil processes through faecal excretion in form of casts, burrows, feeding and digestion (Tian et al., 1995). These earthworms are of great importance especially in vermicomposting, bait, food for fish, birds, etc.

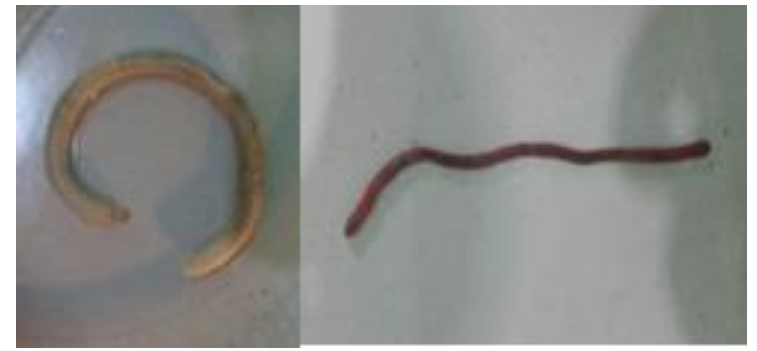

Fig. 2: External feature of $P$. corethrurus

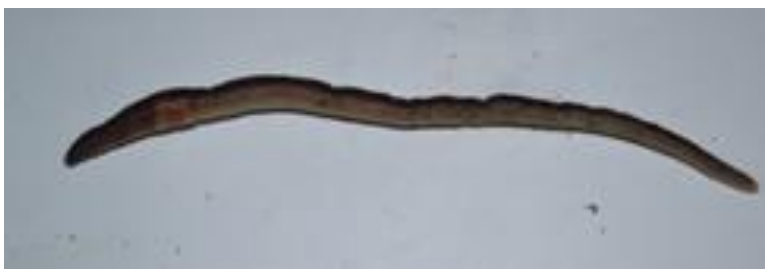

Fig. 3: External feature of Eudrilus eugeniae

The genus Amynthas is one of the invasive and dominant terrestrial earthworm genera that occur throughout Thailand and nearby countries.

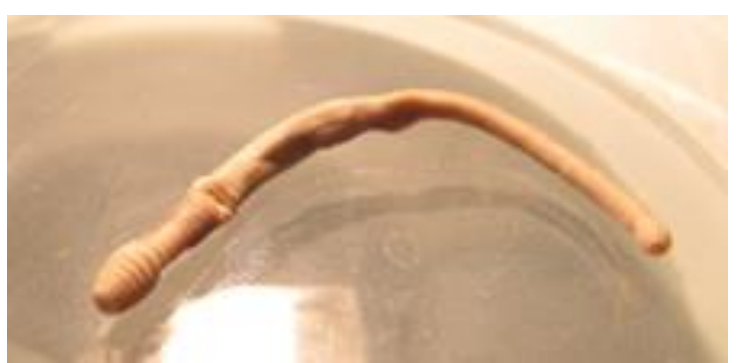

Fig 4: External feature of Amynthas sp

The Pheretima group of species is the largest group of earthworms in the world (Sims and Easton, 1972) from the family Megascolecidae. This species is not applicable in the biological species concept because they have different sizes and anatomically not compatible (Aspe et al., 2009). Members of Family Megascolecidae have annular clitellum. The male pores are a single pair, usually on segment 18 . The female pores are either paired or there is only a single median pore, nearly always on segment 14 . Most of the Pheretima species were darkly pigmented. In the study conducted by Gates (1972).

Two of these species belongs to the family Megascolecidae, one in Glossoscolecidae and one in the family Eudrilidae. There are a lot of samples from the family Glossoscolecidae from each of the ecotype dominating the other species. One species was identified as $P$. corethrurus of Family 
Glossoscolecidae, an exotic species that originated from Brazil (Table 1).

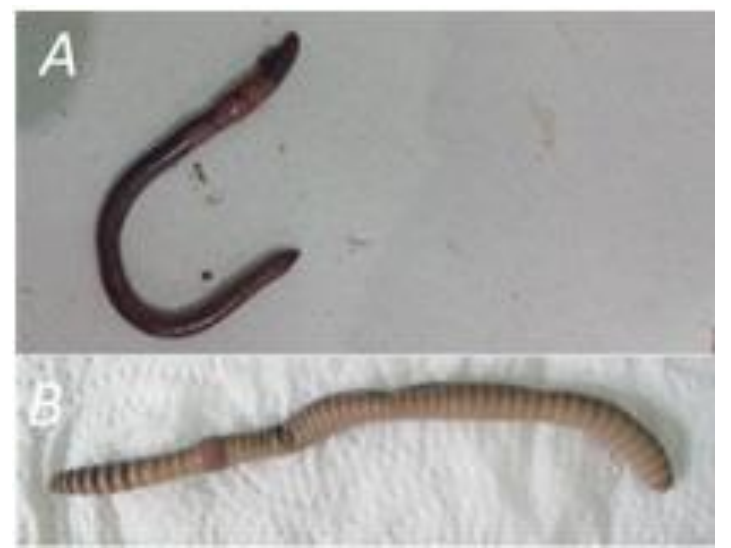

Fig. 5: External features of A. Pheretima sp.1 and B. Pheretima sp. 2

Table 1: Species distribution of earthworms from different ecotypes

\begin{tabular}{cccc}
\hline \multirow{2}{*}{ Species } & \multicolumn{3}{c}{ Ecotype } \\
\cline { 2 - 4 } & Forest & Riverbank & Agriculture \\
\hline Eudrilus eugeniae & - & + & + \\
Pheretima sp. 1 & + & + & - \\
P. corethrurus & + & + & + \\
Amynthas sp. & + & + & + \\
Pheretima sp 2 & + & - & - \\
\hline
\end{tabular}

Table 2 shows that between the 3 different ecotypes forest has the most number of species of earthworms and is the most diverse. This is due to the less anthropogenic activities happening in the area compared to the river and agricultural area. Results also show that there are 3 invasive species that are present in each ecotype. Namely $P$. corethrurus, Eudrilus eugenae, and Amynthas sp. Endogeic worms were present in all the different ecotypes and each of the ecotypes were dominated by $P$. corethrurus. $P$. corethrurus are most abundant in the river side and agricultural area.

\subsection{Forest}

The result of the neighbor joining clustering of earthworm populations above shows two groups from the forest. The result of the study revealed 2 groups of earthworms based on the 63 phenotypic characters used. They are presented as follows:

- Group 1: Clitellum cover is from segments 2-8. Clitellum origin is from segment 12-15. Other individuals don't have a male pore and the other earthworms have their male pore located at segment 13-19. Setal arrangement of this group is very variable that they vary from numerous and arranged equally around each segment (Perichaetine) and setae counts vary in different parts of the body from more than 8 setae per segment to less than 8 in the posterior. Dorsal pores are present in some individuals and are located in segment 12/13. Clitellum shape is annular and also saddle type. There are no genital markings present. Female gonopore is present on some individual. Their pigmentation is brown and pink, some individuals are unpigmented. Prostomium type is tanylobic and epilobic. There are no spermathecal pores present. Last heart location varies from segments 11-17. There are no pre-testicular present. Gizzard locations vary from segments 6-9; 17-25. Testes are absent. Intestinal caeca and copulatory pouches are absent. Spermathecae is located from segment 6-9. Origin of intestine is located on segment is on segment $12,14,15,17,21,25,26$. Seminal vesicles are located on segment 9, 10, 13-15 and 17.

- Group 2: Clitellum is not developed. Male pore is not developed. Setae counts vary in different parts of the body from 8 segments to less than 8 segments in the posterior. There are no spermathecal pores present. There are no setae between male pores. There are no dorsal pores present. There are no genital markings present. There are no female gonopores present. The pigmentation of this group is pink. Prostomium type is tanybolic. Prostates are not present. Last heart location is located on segments 15 and 16 . Nephridia are small and plenty that either scattered (meroic). There are no pretesticular spermathecae present. Gizzard is located on segment 12 . There are no testes present. There are also no intestinal ceaca and copulatory pouches. Origin of intestine is located on 14-15, and 18. Location of seminal vesicles is located on segment 12.

Of the 2 groups, the variations between the 3 species groups were described in Table 2.

\subsection{Agricultural area}

Neighbor joining clustering of individuals in relation to the various identified species of earthworms from the agricultural area revealed 2 groups based on the use of 63 phenotypic characters. The two groups have the following characters:

- Group 1: Clitellum cover is from segments 2-4, 6, 8, and 9. Clitellum origin is from segments 11-14. Male pore location is located on segment 15-18. Dorsal pore is not present. Dorsal pore is absent. Setae of this group vary from numerous and arranged equally around each segment (Perichaetine), setae count vary in different parts of the body from greater than 8 segments to less than 8 segments in the posterior, setae numerous and arrange equally but setae are closer (near). Clitellum shape is annular and saddle type. There are no genital markings. Some individuals have female gonopore present. The pigmentation is pink and brown to dark brown. The prostomium type is epilobic and tanybolic. There are no spermathecal pores present. Some individuals have prostatic gland and are tubular and racemose. Last heart location is on segments 9-14. Location of gizzard is on segments from 12,14, 17 and 23. Testes are 
absent. Intestinal caeca and copulatory pouches are absent. Spermathecae are located on segments 6 and 8. Origin of intestine 15, 17-19, and 21 . Location of seminal vesicles 9-12.

- Group 2: Clitellum covers vary from segments 6, 8, and 9. Clitellum origin is from segments12-14. There are no male pores present. Setae counts vary in different parts of the body from greater than 8 segments in the anterior and less than 8 segments in the posterior. There are no dorsal pores present. Clitellum shape is saddle type. There are no genital markings present. There are no female gonopores present. Prostomium type is tanybolic. This group of earthworms is unpigmented. Some individuals have spermathecae on segments 5-9. Prostatic glands are absent. Nephridia are meroic. There are no testes present. There are no intestinal caeca and copulatory pouches present. Location of gizzard is on segments 12,14 , and 23. Origin of intestine is on segments 19, 21, and 25. Seminal vesicles are located on segment 11, 12, 14, and 15 . Morphological variations of three selected species groups of earthworm populations found in the agricultural area are shown in Table 3.

Table 2: Morphological variations of the different earthworm populations found in the forest area

\begin{tabular}{|c|c|c|c|}
\hline Characters & P.corethrurus & Pheretima sp. & Amynthas sp. \\
\hline Clitellum origin & $13,14,15$ & $13,12,14$ & Absent \\
\hline Clittelum cover & $6,7,8$ & $3,2,5$ & Absent \\
\hline Male pore location & Absent & 18,17 & Absent \\
\hline $\begin{array}{l}\text { Setal } \\
\text { arrangement }\end{array}$ & $\begin{array}{l}\text { setae count vary in different parts } \\
\text { of the body from } 8>8 \text { posterior }\end{array}$ & $\begin{array}{l}\text { setae numerous and arranged equally } \\
\text { around each segment (Perichaetine) }\end{array}$ & $\begin{array}{l}\text { setae count vary in different parts of } \\
\text { the body from } 8>8 \text { posterior }\end{array}$ \\
\hline Dorsal pore & Absent & Present & Absent \\
\hline Clitellum shape & Saddle type & Annular & absent \\
\hline Genital markings & Absent & $18-22$ & Absent \\
\hline Female gonopore & Absent & Paired & Absent \\
\hline Pigmentation & Unpigmented & brown & Pink \\
\hline Spermathecal pore & Absent & Absent & Absent \\
\hline Prostomium type & tanybolic & Epilobic & tanybolic \\
\hline Prostatic gland & Absent & present & Absent \\
\hline $\begin{array}{l}\text { Prostatic gland } \\
\text { location }\end{array}$ & Absent & $17-18$ & Absent \\
\hline $\begin{array}{l}\text { Prostatic gland } \\
\text { Shape }\end{array}$ & Absent & racemose & Absent \\
\hline Last heart location & $9-15,17$ & $10,11,14,16$ & 42721 \\
\hline Location of gizzard & $6,7,9,17,23$ & $6-8,9,10,25$ & 42687 \\
\hline Origin of intestine & $14,16,17,19,21$ & $12,15,21,25$ & 11,12,14,17,18,19, \\
\hline $\begin{array}{l}\text { location of seminal } \\
\text { vesicles }\end{array}$ & $10,11,12,15$ & $9,10,12,14,15$ & Absent \\
\hline
\end{tabular}

Table 3: Morphological variations of the 3 earthworm populations found in the agricultural area

\begin{tabular}{|c|c|c|c|}
\hline Characters & E. Eugeniae & P. corethrurus & Amynthas sp. \\
\hline Genital markings & none & absent & absent \\
\hline Prostonium type & epilobic & Tanybolic & Tanybolic \\
\hline Prostatic gland shape & tubular & absent & absent \\
\hline Last heart location & $9,10,11$ & $10,11,12,14,16$ & $9,10,11,12,14$ \\
\hline Location of gizzard & 14,15 & 14,15 & $14,15,6,23$ \\
\hline Testes & absent & absent & absent \\
\hline Intestinal caeca & absent & absent & absent \\
\hline Copulatory pouches & absent & absent & absent \\
\hline Spermathecae & absent & absent & Absent \\
\hline $\begin{array}{l}\text { Location of } \\
\text { spermathecae }\end{array}$ & absent & absent & absent \\
\hline Origin of intestine & $15,16,18,19,25$ & $18,19,21,25$ & $15,19,21,25$ \\
\hline $\begin{array}{l}\text { location of seminal } \\
\text { vesicles }\end{array}$ & $10,11,12$ & $11,12,13,14,15$ & 11 \\
\hline Clitellum cover & 4,10 & $9,8,10$ & Absent \\
\hline Clittelum origin & 12,13 & $12,13,14$ & absent \\
\hline Male pore location & 16,17 & Absent & abset \\
\hline Setal arrangement & $\begin{array}{c}\text { setae numerous and arranged equally } \\
\text { around each segment }\end{array}$ & $\begin{array}{l}\text { setae count vary in different } \\
\text { parts of the body }\end{array}$ & $\begin{array}{c}\text { setae numerous and arrange equally but } \\
\text { setae are closer(near) }\end{array}$ \\
\hline Setae between MP & present & Absent & absent \\
\hline Dorsal pore & absent & absent & absent \\
\hline Clitellum shape & Saddle type & Saddle type & absent \\
\hline
\end{tabular}




\subsection{Riverbank}

Neighbor joining clustering of individuals in relation to the various identified species of earthworms from the riverbank based on morphological variations reveals 2 groups of earthworms from the riverbank area. Using the 63 phenotypic characters the two groups has the following characters:

- Group 1: Clitellum cover is from segments 2-4, 6-8, and some individuals don't have clitellum at all. Those individuals who have clitellum have their clitellum originated from segments 11-15, and 17. Male pores are located on 13 and 16-18. Setal arrangements vary from setae numerous and arranged equally around each segment (Perichaetine) and setae counts vary in different parts of the body from greater than 8 setae per segment and less than 8 setae per segment in the posterior. Dorsal pores are absent. Clitellum shape varies from annular and saddle type. Some individuals have genital markings present on segments 10-12, 19-22, and 18-22. Spermathecal pores are absent. Prostatic glands are present and vary in shape from tubular and racemose. Some individuals have pre-testicular spermatheca present. Location of gizzard varies on segments 7 ,
$12,14,17,23$, and 25 . Some individuals in this group have their testes located on segments 6 and 7. Intestinal caeca and copulatory pouches are absent. Those individuals who have their spermatheca present are located on segments 6-8. Origin of intestine varies on segments 14, 15, 19, 21 , and 25 . Location of the seminal vesicles are located on segment 9, and 11-13 (Table 4).

- Group 2: Clitellum cover is from segments 6-9. Clitellum origin is 12 and 13 . Male pore is not present. Setae counts vary in different parts of the body from more than 8 setae per segment to less than 8 setae in the posterior. Dorsal pore is not present. There are no female gonopores. This group is unpigmented. Prostomium type is tanybolic. There are no spermathecal pores present. Prostatic glands are absent. Last heart location is on segments 9, 11, 12 and 15. Nephridia are single pair or holoic. There are no pre-testicular spermatheca present. Location of gizzard is on segments 14, 17, and 20. Testes are absent. Intestinal caeca and copulatory pouches are absent. Origin of intestine is on segments 21 and 25 . Seminal vesicles are absent. Morphological variations of selected earthworm populations found in the riverbank area are shown in Table 4.

Table 4: Morphological variations of the different earthworm populations found in the riverbank area

\begin{tabular}{|c|c|c|c|c|}
\hline Characters & E. Eugeniae & P. corethrurus & Pheretima $s p$. & Amynthas sp. \\
\hline Clitellum cover & $3,4,5$ & $9,8,10$ & $3,2,3$ & absent \\
\hline Clittelum origin & $9,13,14,7$ & $12-15$ & $12-15$ & absent \\
\hline Male pore location & $13,16,17,18$ & Absent & 17,18 & \\
\hline Setal arrangement & $\begin{array}{l}\text { setae numerous and } \\
\text { arranged equally around } \\
\text { each segment }\end{array}$ & $\begin{array}{l}\text { setae count vary in } \\
\text { different parts of the } \\
\text { body }\end{array}$ & $\begin{array}{c}\text { setae numerous and } \\
\text { arranged equally around } \\
\text { each segment }\end{array}$ & $\begin{array}{l}\text { setae numerous and arrange } \\
\text { equally but setae are } \\
\text { closer(near) }\end{array}$ \\
\hline Setae between MP & present & Absent & present & absent \\
\hline Dorsal pore & absent & absent & $\begin{array}{l}\text { Present } \\
12-13\end{array}$ & absent \\
\hline Dorsal pore & absent & absent & $\begin{array}{l}\text { Present } \\
12-13\end{array}$ & absent \\
\hline $\begin{array}{l}\text { Clitellum shape } \\
\text { Genital markings }\end{array}$ & $\begin{array}{c}\text { Saddle type } \\
\text { none }\end{array}$ & $\begin{array}{l}\text { Saddle type } \\
\text { absent }\end{array}$ & $\begin{array}{c}\text { annular } \\
18-22\end{array}$ & $\begin{array}{l}\text { absent } \\
\text { absent }\end{array}$ \\
\hline Clitellum shape & Saddle type & Saddle type & annular & absent \\
\hline Last heart location & $9,10,12$ & $9-13,16$ & $11-14,17$ & $10-148 / 2 / 2016$ \\
\hline $\begin{array}{l}\text { Location of } \\
\text { gizzard }\end{array}$ & $7,14,17,23$ & $13-15$ & $13-15$ & $11,13,14,15$ \\
\hline Testes & absent & absent & $\begin{array}{l}\text { Present } \\
5,7,11\end{array}$ & absent \\
\hline Intestinal caeca & absent & absent & absent & absent \\
\hline $\begin{array}{l}\text { Copulatory } \\
\text { pouches }\end{array}$ & absent & absent & Absent & absent \\
\hline Spermathecae & absent & absent & Present & Absent \\
\hline $\begin{array}{l}\text { Location of } \\
\text { spermathecae }\end{array}$ & absent & absent & $6-8$ & absent \\
\hline Origin of intestine & $17,19,21,25$ & $14,17,18,19,25$ & $14,16,17,28,21$ & $12,14,18,19,25,26$ \\
\hline $\begin{array}{c}\text { location of } \\
\text { seminal vesicles }\end{array}$ & $9,11,15$ & $9-14$ & $9-13,17$ & $12,13,14$ \\
\hline
\end{tabular}

Results of this study have shown the wide distribution of the different earthworm groups. Earthworms play an ecological significance in the part of the biodiversity since there are many fauna and flora that depends on them. While there are few information about interactions between native and non-native species, they are however critical to understanding the potential consequences of ongoing biological invasions. The existence of biological invasions in soil is largely overlooked because soil is an opaque medium, where the biota is inconspicuous (Hendrix and Bohlen, 2002; Ehrenfeld 
and Scott, 2001). In the study conducted by Zou et al. (2006) the conversion of the natural environment to industrialized environment will lead the anecic earthworms mostly the native ones to disappear because it decreases the soil surface litter due to disturbances that leads to the dominance of the endogeic species $P$. corethrurus. P. corethrurus can borrow deep into mineral soil layers and regenerate rapidly even in nutrient poor soils (Lavelle et al., 1999) and this explains why this species has a high density in agricultural area.

The destruction of the natural habitat causing alteration in the chemical and physical properties of the soil most likely hampered the development and activity of the native earthworms; thus, alter the earthworm community structures in these areas (Aspe et al., 2009). The destruction of the natural habitat by anthropogenic activities, which drastically affected the soil environment and most likely favored the establishment of the widespread introduced species P. corethrurus (Aspe et al., 2009). P. corethrurus has been said to be "the most widely distributed earthworm" though that honor also has been claimed for several lumbricid species (Gates, 1972).

The occurrence of the exotic species in the farmlands, grasslands and the disturbed forests is most likely associated with anthropogenic activities. When the forest was converted to industrialized lands, their natural habitat has been destroyed resulting in the loss of the native species as the cultivated lands became favorable for the propagation of the exotic species. This group of species is also abundant in the agricultural area because they are able to thrive in the harsh and stressful environment in the farmlands due to the use of pesticides where the native species cannot (Aspe et al., 2009). Human immigration and sustained anthropogenic activities favored the establishment of $P$. corethrurus, which also is responsible for the disappearance of the native species in the area from the study conducted by Lapied and Lavelle (2003). P. corethrurus do not necessarily require a mate for them to reproduce and that they have the ability to start a new population by only one individual. That may explain its rapid population growth, which is a big advantage over the other species (Aspe et al., 2009).

Introduced species like Pheretima also dominate the earthworm fauna in most soils. A general feature is that native earthworm species are found in relatively undisturbed soils whereas introduced species are more likely to be encountered in disturbed soils (Hendrix, 1995; Kalisz and Dotson, 1989). A study conducted by Callaham et al. (2002) shows there are greater than $75 \%$ of the total number of earthworms collected were exotic species and only at least $20 \%$ consisted of juvenile lumbricids that may have been native or exotic species (the family Lumbricidae is represented by both native and introduced species in the samples studied in this study).

\section{Conclusion}

The overwhelming abundance of exotic species in the site where there is less or non-anthropogenic activities are quite alarming. This study shows that even the undisturbed sites are also dominated by exotic species like $P$. corethrurus.

\section{References}

Apuan DA, Torres MAJ, and Demayo CG (2010). Describing variations and taxonomic status of earthworms collected from selected areas in Misamis Oriental, Philippines using principal component and parsimony analysis. Egyptian Academic Journal of Biological Sciences, B, Zoology, 2: 27-36.

Aspe NM, Nuñeza OM, and Torres MA (2009). Diversity and distribution of earthworms in Mt. Malindang, Philippines. Journal of Nature Studies, 8: 59-67.

Blackburn JC (1989). External anatomy of earthworms. Science, 207: 2572-2577.

Callaham MA, Stewart AJ, Alarcón C, and McMillen SJ (2002). Effects of earthworm (Eisenia fetida) and wheat (Triticum aestivum) straw additions on selected properties of petroleum-contaminated soils. Environmental Toxicology and Chemistry, 21(8): 1658-1663.

Ehrenfeld JG and Scott N (2001). Invasive species and the soil: Effects on organisms and ecosystem processes. Ecological Applications, 11(5): 1259-1260.

Fragoso C and Lavelle P (1992). Earthworm communities of tropical rain forests. Soil Biology and Biochemistry, 24(12): 1397-1408.

Gates GE (1972). Burmese earthworms: An introduction to the systematics and biology of megadrile oligochaetes with special reference to Southeast Asia. Transactions of the American philosophical Society, 62(7): 321-326.

Hendrix PF (1995). Earthworm ecology and biogeography in North America. CRC press, Boca Raton, USA.

Hendrix PF and Bohlen PJ (2002). Exotic earthworm invasions in North America: Ecological and policy implications expanding global commerce may be increasing the likelihood of exotic earthworm invasions, which could have negative implications for soil processes, other animal and plant species, and importation of certain pathogens. Bioscience, 52(9): 801-811.

James SW (2004). New species of Amynthas, Pheretima and Pleionogaster (Clitellata: Megascolecidae) of the Mt. Kitanglad range, Mindanao island, Philippines. The Raffles Bulletin of Zoology, 52(2): 289-313.

Kalisz PJ and Dotson DB (1989). Land-use history and the occurrence of exotic earthworms in the mountains of eastern Kentucky. American Midland Naturalist, 122: 288-297.

Lapied E and Lavelle P (2003). The peregrine earthworm Pontoscolex corethrurus in the east coast of Costa Rica. Pedobiologia, 47(5-6): 471-474.

Lavelle P, Brussard L, and Hendrix PF (1999). Earthworm management in tropical agroecosystems. CABI Publishing, Oxford, UK.

Liu ZG and Zou XM (2002). Exotic earthworms accelerate plant litter decomposition in a Puerto Rican pasture and a wet forest. Ecological Applications, 12(5): 1406-1417.

Paoletti MG (1999). The role of earthworms for assessment of sustainability and as bioindicators. Agriculture Ecosystems and Environment, 74(1): 137-155.

Rickart EA, Heaney LR, and Utzurrum RC (1991). Distribution and ecology of small mammals along an elevational transect in southeastern Luzon, Philippines. Journal of Mammalogy, 72(3): 458-469. 
Segun AO (1998). Tropical zoology. University Press PLC, Ibadan, Nigeria.

Sims RW and Easton EG (1972). A numerical revision of the earthworm genus Pheretima auct, (Megascolecidae: Oligochaeta) with the recognition of new genera and an appendix on the earthworms collected by the Royal Society North Borneo Expedition. Biological Journal of the Linnean Society, 4(3): 169-268.

Suarez RK and Sajise PE (2010). Deforestation, swidden agriculture and Philippine biodiversity. Philippine Science Letters, 3(1): 91-99.
Tian G, Brussaard L, and Kang BT (1995). Breakdown of plant residues with contrasting chemical compositions under humid tropical conditions: Effects of earthworms and millipedes. Soil Biology and Biochemistry, 27(3): 277-280.

Zou X, Pérez BA, Santiago DCR, Gutiérrez J, and Santiago MR (2006). Comparisons of earthworm community structure between an active pasture and an adjacent tropical wet forest in Puerto Rico. Caribbean Journal of Science, 42(3): 311-314. 